\title{
Blast Response of Elevated Water Tank Staging with Metallic Damper
}

\author{
Boda Balaraju' ${ }^{1}$ Atulkumar Manchalwar ${ }^{2}$ \\ ${ }^{1}$ M. Tech Scholar, Gokaraju Rangaraju Institute of Engineering and Technology, Hyderabad, India \\ ${ }^{2}$ Associate Professor, Gokaraju Rangaraju Institute of Engineering and Technology, Hyderabad, India
}

\begin{abstract}
In the present paper work an attempt has been made to study the dynamic behaviour of the elevated water tank staging by using x-plate metallic damper subjected to blast induced ground vibrations. The main objective of this study is to reduce the damage of the elevated water tank by providing structural response control devices. The water tank staging is modelled in SAP 2000 and non-linear time history analysis is carried out to know the performance of the metallic damper under four different intensity blast induced ground motions and comparing the performance of structure without damper case. After the completion of analysis, the results show that by using metallic damper bending moment, shear force and displacements are comparatively reduced when compared to the without damper case. From this study observed that metallic x-plate damper is effectively reduced the structural responses under blast excitations.
\end{abstract}

\section{Introduction}

Elevated water tanks are very important structures to supply water for public utility and firefighting demand. These are expected to be serviceable during and after severe earthquakes and blast explosions. The elevated water tanks have huge amount of mass concentrated at the top, and it is resting on the slender supporting structure so it is more vulnerable against lateral forces due to earthquake and blast loads. It is important to consider dynamic motion of water with respect to tank as well as tank motion with respect to ground. During the blast explosion greater amount of energy is produced and this energy is causes to structural damage. Many of the elevated water tanks are collapsed due to poor staging performance during the earthquake and blast. To reduce the structural damage by introducing the energy taking devices such as dampers and base isolators. In this paper to control the displacement, displacement control dampers are used and it gives additional stiffness to the structure.

In recent years, many researchers investigated the effectiveness of dampers on elevated water tank staging. Panchal and jangid [1] worked on the seismic response of liquid storage steel tanks isolated with using variable frequency pendulum isolators and compared with friction pendulum systems. Shekari.et.al, [2] worked on the seismic behavior of cylindrical base isolated liquid storage structures and concluded that by using isolation system the dynamic behavior of tanks during earthquake ground motions can be considerably decreases. Seleemah.et.al, [3] base isolation was indicated to be more efficient for slender tanks as compared with broad tanks under seismic loads. Mohammed Zain kanga et.al,
[4] concluded low damping isolator is found to be more effective in response reduction ability than high damping isolator and LRB is more effective in decreasing structural accelerations and story drifts. Manchalwar and Bakre [5] studied on the performance of RC structure equipped with steel and aluminum x plate damper. Manchalwar and Bakre [6] worked on the optimal placement of metallic damper based on concept of generic algorithm. Nirmala G.et al, [7] worked on the vibrational mitigation of water tank staging equipped with $\mathrm{x}$ - plate metallic damper. Nirmala G and atulkumar studied [8] studied behavior of the water tank staging with steel and aluminum $\mathrm{x}$ - plate damper.

\section{X-Plate metallic damper}

$\mathrm{X}$-Plate metallic damper is one type of damper which configuration is in $\mathrm{X}$ shape and this damper made up of steel and aluminum. The XPD provides to reduce the deformation and it is very efficient in the reduction of energy. This XPD consists of multiple x-plate connections. The number of metallic plates is depending on the structural system type to exhaust the input external energy. The XPD provides additional stiffness and damping to the system.

The various researchers studied on the x-plate damper and analyze the effectiveness of the damper. Manchalwar and Bakre [9] investigated on the steel and aluminum metallic $\mathrm{x}$-plate damper on reinforced concrete structures and they found the $\mathrm{x}$ - plate dampers are very efficient to reduce the seismic and blast performance. In BARC (Bhabha atomic research center), IIT Mumbai tested many experiments to evaluate the x-plate damper performance. 

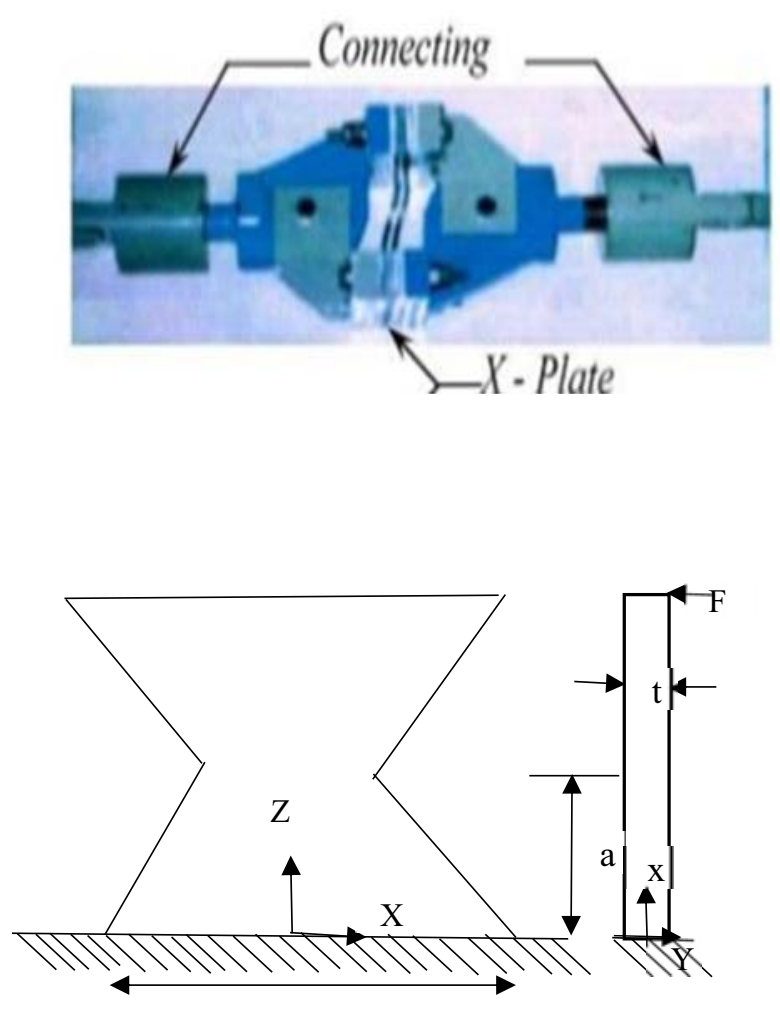

Fig.1. X-plate metallic damper

Properties of metallic X-plate damper: -

$$
\begin{gathered}
F_{y}=\frac{\sigma_{y} b t^{2}}{6 a} n \\
q=\frac{2 \sigma_{y} a^{2}}{E t} \\
K_{d}=\frac{F_{y}}{q} \\
K_{d}=\frac{E b t^{3}}{12 a^{3}} n
\end{gathered}
$$

Where, $F_{y}$ is the yield force, $K_{d}$ is the initial stiffness of $X-$ plate damper, $\mathrm{q}$ is the yield displacement. $\mathrm{a}, \mathrm{b}$ and $\mathrm{t}$ are indicating the height, width and damper thickness. $\sigma_{y}$ and $\mathrm{E}$ are yield stress and young's modulus of the damper.

Table 1. Sectional properties of the water tank

\begin{tabular}{|c|c|c|c|c|}
\hline $\begin{array}{c}\text { Capacity } \\
\text { of the } \\
\text { tank (ML) }\end{array}$ & $\begin{array}{c}\text { Tank } \\
\text { diameter } \\
(\mathrm{m})\end{array}$ & $\begin{array}{c}\text { Size of } \\
\text { column } \\
(\mathrm{mm})\end{array}$ & $\begin{array}{c}\text { Bottom } \\
\text { beam } \\
(\mathrm{mm})\end{array}$ & $\begin{array}{c}\text { Brace } \\
\text { beam } \\
(\mathrm{mm})\end{array}$ \\
\hline 0.6 & 11.38 & $\begin{array}{c}400 \mathrm{x} \\
400\end{array}$ & $\begin{array}{c}350 \mathrm{x} \\
750\end{array}$ & $\begin{array}{c}300 \mathrm{x} \\
550\end{array}$ \\
\hline
\end{tabular}

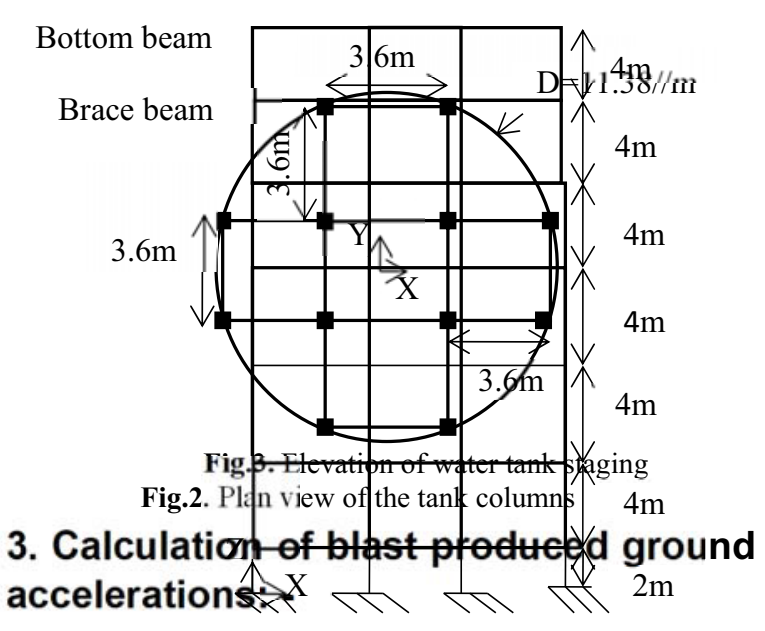

based on the earlier research by Hinman [10], Carvalho and Battista [11] are proposed the one exponential decaying function for blast induced ground vibrations in terms of ground acceleration in the form of equation.

$$
\ddot{x}_{g}(t)=-\frac{1}{t_{d}} v e^{\frac{-t}{t_{d}}}
$$

In the above equation $\ddot{x}_{g}(t)$ is the ground acceleration, $t_{d}$ is the arrival time of wave calculated by $t_{d}=R / C, C$ is the velocity of wave and $\mathrm{R}$ is the $\mathrm{d}$ charge point distance for present study it is taken as $100 \mathrm{~m} . \mathrm{v}(\mathrm{m} / \mathrm{s})$ is peak particle velocity which is proposed by Kumar et al., [12]

$$
\mathrm{V}=\frac{f^{0.642} S D^{-1.463}}{\gamma_{D}}
$$

Where $\mathrm{f}$ is the uniaxial compressive strength of granite rock deposit, $\mathrm{SD}$ is the scaled distance $\mathrm{SD}=\mathrm{R} / \sqrt{Q}, \mathrm{Q}$ is the charge weight in this present study it is taken as 10 ton, 25-ton, 50-ton, 75-ton. $\gamma_{D}$ average mass density of granite is $26000 \mathrm{~kg}$ per cubic meter, young's modulus of granite rock is 73.9 Gpa these are taken from Kumar et al., [12]

\section{Problem statement: -}

To evaluate the blast progress of the water tank structure by using $\mathrm{x}$ - plate steel damper for this study 12 column $24 \mathrm{~m}$ height staging has been selected and modeled in SAP 2000. Plan and elevation of the elevated water tank is 
taken from the Suraj O. Lakhade [13] which is shown in fig. 2\&3. In this study M20 concrete and Fe 500 steel is used. For design dead loads and live loads are considered as per IS 875- 1983 of part $1 \& 2$.

\section{Performance of the structure: -}

To assess the efficiency of the steel $\mathrm{x}$-plate damper, the non-linear time history analysis has been conducted in SAP 2000 under four blast ground vibrations. The yield strength and stiffness of the damper $43.2 \mathrm{kN}$ and $23288.4 \mathrm{kN} / \mathrm{m}$ respectively.

\subsection{Axial force, Shear force and Bending moment comparison: -}

From the analytical results, the response parameters axial force, shear force and bending moment of water tank as shown in table 2,3 and 4 respectively. After analyzing results, it is noticed that axial force gradually decreased, shear force and bending moment values are effectively reduced when compared without X-plate damper case.

Table 2 Axial and comparison for 12 column $24 \mathrm{~m}$ staging.

Table 3 shear force comparison for 12 column $24 \mathrm{~m}$ staging.

Table 4 Bending moment comparison for 12 column $24 \mathrm{~m}$ staging

\begin{tabular}{|c|c|c|c|}
\hline \multirow{2}{*}{$\begin{array}{l}\text { Column } \\
\text { number }\end{array}$} & \multirow{2}{*}{$\begin{array}{c}\text { Blast } \\
\text { charge } \\
\text { weight }\end{array}$} & \multicolumn{2}{|c|}{ Axial force $(\mathrm{kN})$} \\
\hline & & $\begin{array}{l}\text { Without } \\
\text { damper }\end{array}$ & With XPD \\
\hline \multirow{4}{*}{14} & 10 Ton & 117.1 & 75.4 \\
\hline & 25 Ton & 227.3 & 272.3 \\
\hline & 50 Ton & 380.4 & 1141.4 \\
\hline & 75 Ton & 511.5 & 433.0 \\
\hline \multirow{4}{*}{8} & 10 Ton & 1402.7 & 1044.9 \\
\hline & 25 Ton & 2722.1 & 3765.7 \\
\hline & 50 Ton & 4555.8 & 14412.8 \\
\hline & 75 Ton & 6124.7 & 5769.06 \\
\hline
\end{tabular}

\subsection{Displacement comparison: -}

To estimate the effectiveness of the metallic x-plate

\begin{tabular}{|c|c|c|c|}
\hline \multirow{2}{*}{$\begin{array}{l}\text { Column } \\
\text { number }\end{array}$} & \multirow{2}{*}{$\begin{array}{l}\text { Blast } \\
\text { charge } \\
\text { weight }\end{array}$} & \multicolumn{2}{|c|}{ Shear force $(\mathrm{kN})$} \\
\hline & & $\begin{array}{l}\text { Without } \\
\text { damper }\end{array}$ & With XPD \\
\hline \multirow{4}{*}{14} & 10 Ton & 116.8 & 78.1 \\
\hline & 25 Ton & 226.8 & 276.8 \\
\hline & 50 Ton & 379.6 & 1146.0 \\
\hline & 75 Ton & 510.3 & 438.1 \\
\hline \multirow{4}{*}{8} & 10 Ton & 139 & 101.0 \\
\hline & 25 Ton & 269.7 & 356.5 \\
\hline & 50 Ton & 451.4 & 1395.0 \\
\hline & 75 Ton & 606.9 & 550.7 \\
\hline
\end{tabular}

damper, nonlinear time history analysis is conducted and plotted the time history graphs between displacement $(\mathrm{KN})$ and time $(\mathrm{sec})$. Graphs are plotted for four different blast induced ground accelerations. From the results, the $\mathrm{x}$-plate damper is very effectively reduced the displacements when compared to the no damper case shown in Fig.4..

\begin{tabular}{|c|c|c|c|}
\hline \multirow{2}{*}{$\begin{array}{l}\text { Column } \\
\text { number }\end{array}$} & \multirow{2}{*}{$\begin{array}{c}\text { Blast } \\
\text { charge } \\
\text { weight }\end{array}$} & \multicolumn{2}{|c|}{ Bending moment ( $\mathrm{kN} \mathrm{m}$ ) } \\
\hline & & $\begin{array}{l}\text { Without } \\
\text { damper }\end{array}$ & With XPD \\
\hline \multirow{4}{*}{14} & 10 Tons & 352.38 & 310.01 \\
\hline & 25 Tons & 683.80 & 947.91 \\
\hline & 50 Tons & 1144.45 & 3565.78 \\
\hline & 75 Tons & 1538.55 & 1425.8 \\
\hline \multirow{4}{*}{8} & 10 Tons & 215.40 & 156.60 \\
\hline & 25 Tons & 417.99 & 552.84 \\
\hline & 50 Tons & 699.58 & 875.9 \\
\hline & 75 Tons & 940.48 & 853.68 \\
\hline
\end{tabular}



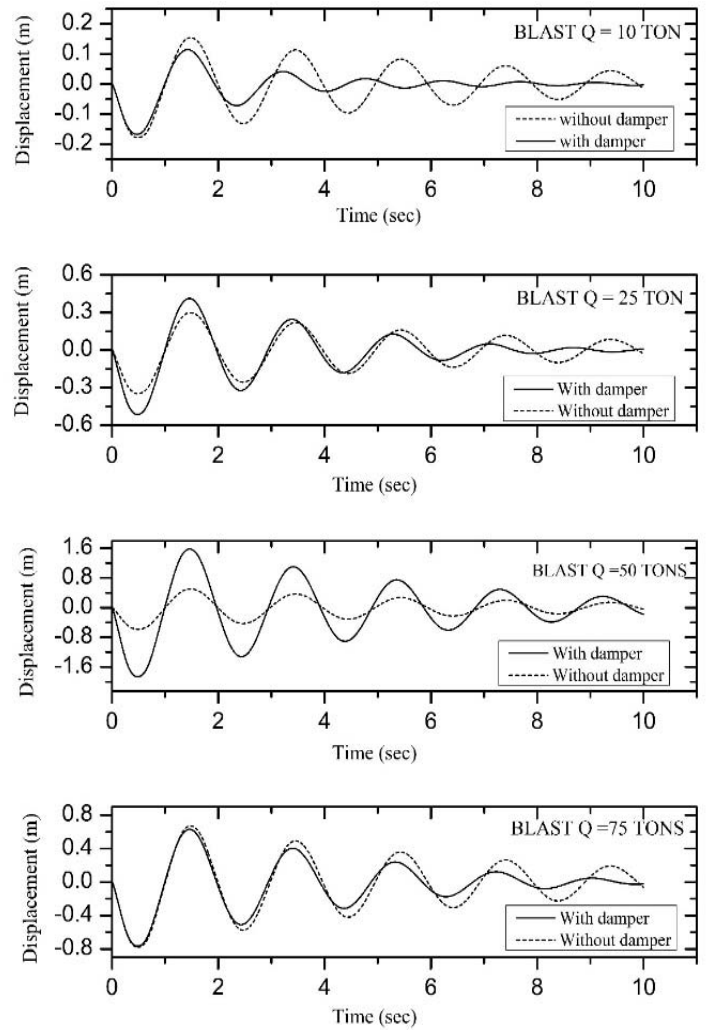

\subsection{Hysteresis loop: -}

Hysteresis loop indicates energy dissipation of damper in the structure it is related to the axial force and displacement. By using steel metallic damper, the energy will be efficiently reduced when subjected to the blast vibrations shown in fig.5.
Fig.4. Displacement vs time of metallic steel damper for 12 column $24 \mathrm{~m}$ staging
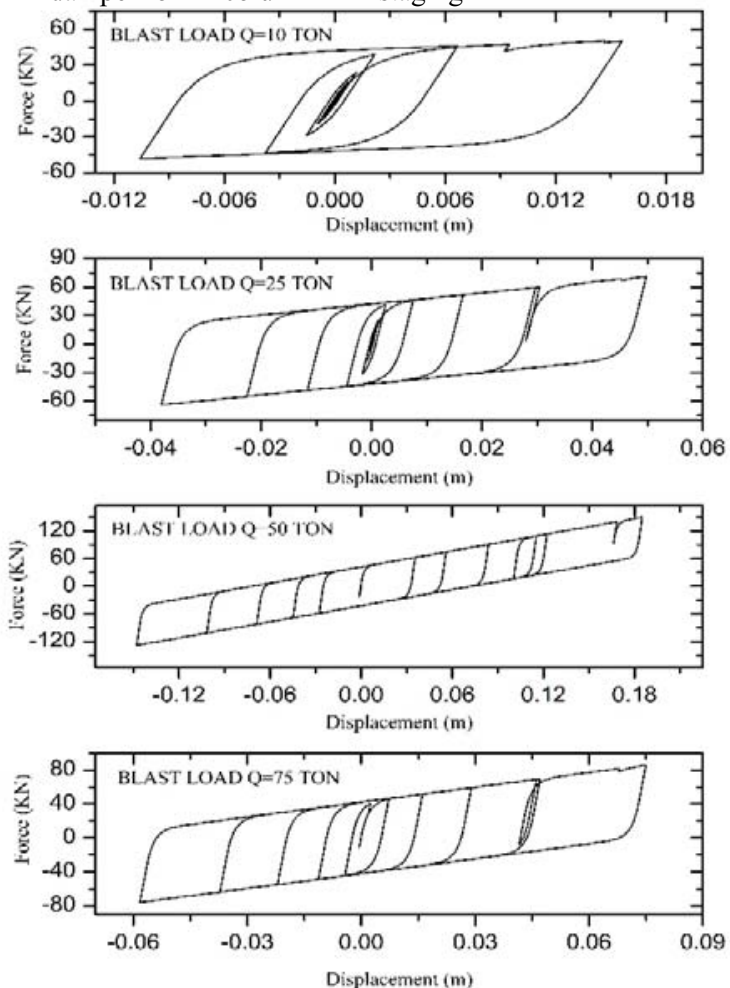

Fig.5. hysteresis loop of 12 column 24 m staging 


\section{Conclusion: -}

In the present study, blast response of water tank is analyzed with metallic damper and without damper. For this study 12 column $24 \mathrm{~m}$ is considered, Modeling of water tank and nonlinear time history analysis is performed in SAP 2000. The main aim of this study to reduce the damage of the water tank when subjected to blast induced ground motions. By using metallic dampers axial force, shear force and bending moment values are effectively reduced for 10 ton and 75-ton blast loads. For 25 ton and 50-ton blast loads the responsive parameters are slightly increases as compared to the without damper. From the results, concluded that top story displacement values are reduced about $25-30 \%$ in metallic damper case.

\section{References}

1. Panchal, V. R., and R. S. Jangid. "Variable friction pendulum system for seismic isolation of liquid storage tanks." Nuclear Engineering and Design 238.6 (2008): 1304-1315.

2. Shekari, M. R., N. Khaji, and M. T. Ahmadi. "On the seismic behaviour of cylindrical base-isolated liquid storage tanks excited by long-period ground motions." Soil Dynamics and Earthquake Engineering 30.10 (2010): 968-980.

3. Seleemah, Ayman A., and Mohamed El-Sharkawy. "Seismic response of base isolated liquid storage ground tanks." Ain Shams Engineering Journal 2.1 (2011): 33-42.

4. Kangda, Muhammed Zain, and Sachin Bakre. "The effect of LRB parameters on structural responses for blast and seismic loads." Arabian Journal for Science and Engineering 43.4 (2018): 1761-1776.

5. Manchalwar, A., and S. V. Bakre. "Performance of $\mathrm{RC}$ structures equipped with steel and aluminium Xplate dampers." Journal of The Institution of Engineers (India): Series A 97.4 (2016): 415-425.

6. Kotkunde, N., Krishna, G., Shenoy, S.K., Gupta, A.K., Singh, S.K. International Journal of Material Forming, 10 (2), pp. 255-266 (2017)

7. Govardhan, D., Kumar, A.C.S., Murti, K.G.K., Madhusudhan Reddy, G. Materials and Design, 36, pp. 206-214. (2012)

8. Kumar, P., Singhal, A., Mehta, S., Mittal, A. Journal of Real-Time Image Processing, 11 (1), pp. 93-109. (2016)

9. Raghunadha Reddy, T., Vishnu Vardhan, B., Vijayapal Reddy, P. International Journal of Applied Engineering Research, 11 (5), pp. 3092-3102 (2016)

10. Hussaini, S.M., Krishna, G., Gupta, A.K., Singh, S.K. Journal of Manufacturing Processes, 18, pp. 151-158 (2015) 